\title{
Chapter Fourteen: Insider Theory and the Construction of Statelessness
}

Phil Cole

\section{Introduction: the radical role of theory}

Many of the essays in this edited collection are very applied and practical, examining empirical evidence and policy development around migrancy and statelessness. This essay, in contrast, works at the level of political theory in what may strike some as a very abstract level. It is, in a sense, radically theoretical, in that it looks at political theory itself as a subject for study, and at statelessness, not as a phenomenon in the world, but as a theoretical concept. What I want to examine is the way in which liberal political theory gives statelessness its shape and content. It is important, I believe, to look at theory, because even the most applied essay is drawing on a set of ideas and concepts such as the state, the citizen and the nation, and while those ideas are reflected in political practice they also have a theoretical history, and to the extent that our task in all of our essays is evaluative and critical, not merely descriptive, we are drawing on that theoretical background.

It is theory that enables evaluation and critique to take place, because it is at the level of theory that we can imagine alternative possibilities to the current order, and so ask why that current order persists when there are superior possibilities available to us. This means that our discussions are not limited by states, citizenship or nations as we find them in the world, but can explore alternatives as we use theory to imagine different political orders. And if some respond by saying our work is not rooted sufficiently in the real world, we should also remember that the systems of citizenship and exclusion that are actually practiced by states are, in an important sense, not part of the real world, but are themselves constructs. Current political practices of membership are contingent, perhaps even arbitrary, and are mostly very recent developments, and so there is no good reason why they should constitute the limits of our thinking about migration, membership and statelessness. Indeed, what we should keep in mind is that statelessness is a condition created and sustained by those 
contingent, arbitrary and recent political practices, and so thinking beyond them is an urgent necessity. This essay is, therefore, radical in a second sense, in that I want to push our imagination as far as possible beyond the current political order, and imagine what a just world would be like even if that means radically revising practices of citizenship, migration and nation-states.

One question we have to consider, though, is whether there are any practical limitations on our thinking when it comes to imagining different possible political orders. Joseph Carens (2013) asks this in his discussion of the ethics of immigration. ${ }^{1}$ He makes a distinction between what he calls the Just World Presupposition and the Real World Presupposition. The Just World Presupposition imagines what a just world should be like with the idea of justice as unqualified and absolute. Amongst other things, “....an exploration of what justice ideally entails with respect to immigration should take the whole world into account" (301). The Just World Presupposition allows us to critique the current world order to the extent that it fails to meet ideal standards of justice, but Carens points to the disadvantage that we are in constant danger of losing our bearings. In looking at what justice ideally demands in relation to statelessness, we will find that we need a wider moral theory dealing with the human good in general. We can't propose what the right to membership ideally demands without a general theory of human rights, and we know that it is notoriously difficult to ground a general theory of human rights.

The Real World Presupposition constrains us to thinking about what justice demands with respect to statelessness in the context of the world as we find it, both institutionally (a world of nation-states) and ethically (a world in which certain principles are taken for granted, such as nation-state sovereignty when it comes to membership). This Real World Presupposition is on the continuum near to where things actually are but is not right at the end, as there is still room to criticize how things stand - it is not merely descriptive. The advantage is that our arguments will be relevant to policy debates, but the disadvantage is that we may not see deep structural injustices. Carens argues that his own approach, which he calls the Democratic 
Principles Presupposition, lies somewhere between these two 'extremes'. I will not discuss his approach here ${ }^{2}$, but simply recognize that my work takes place within the space constitutes by the Just World Presupposition, and that the Real World Presupposition itself, as Carens says, opens up some critical space between practice and possibilities. Once that space it opened, it seems to me, we, as theorists, should see how far we can go.

However, my primary focus in this essay is liberal political theory and so I will say little about current political practices and possible alternatives, however radical. In a sense, this essay is the groundwork for that radical vision, by exposing and therefore overcoming limitations on our imagination that are embedded at the level of theory. I argue that liberal theory is itself a practice, and as such has limits which could be, on examination, exposed as contingent, and perhaps even arbitrary. It is not a 'pure' space free of contingent limitations upon how we think, and so those limitations must be exposed and critically examined to see if we ought to move beyond them. And so the object of my enquiry is liberal theory itself, and the concept of statelessness it constructs.

The conceptual argument is that the concept of statelessness is a space which has boundaries and a shape. It stands opposed to the opposite space of citizenship, which itself has boundaries and a shape. Indeed, we might argue that it is the space and content of citizenship that defines the space and content of statelessness. The stateless lack the properties necessary to enter the space of citizenship, and so are confined to the space of statelessness. But what is it that they lack? Certainly, it looks as though our attention should be on the concept of citizenship, to see whether it is drawing boundaries in an arbitrary manner, but that is hard to do and draws us away from theory towards practice, as there is no single agreed theoretical model of citizenship that states are using in their practices. And so the reasons why people are confined to the political space of statelessness are diverse. What work can we do here at the level of theory, beyond imagining an ideal model of citizenship which would not create statelessness? That work is important, once we realize that it is how we construct 
citizenship that creates the stateless (the stateless as an externality of citizenship). However, in this essay I want to do something quite different.

I want to focus on the figure of the stateless person in theory, and ask if there is something about them that leads them to be confined to the theoretical space of statelessness. It may be that they lack certain properties, but they may also possess certain properties that lead to their confinement - they possess certain undesirable properties that have to be positively excluded from the realm of citizenship. It may be that this figure is constructed at the level of liberal political theory in ways that are contingent, arbitrary and non-rational, and, possibly, irrational. And while some would argue there must be space in political theory for the contingent, arbitrary and non-rational ${ }^{3}$, my argument in this essay is that there are elements of the construction of the stateless figure that take us into the realm of the irrational. And so this claim is more than that political theory must take into account the non-rational and irrational, in the form of the emotions of fear and anger, for example, but that political theory itself is formed, to some extent, by the non-rational and the irrational, and we can witness this by examining the shape and form and role of the stateless in political theory.

\section{Residual or structural statelessness}

In international development theory there are, broadly speaking, two ways of understanding global poverty, known as the residual view and the structural view. The residual view largely emerges from neo-liberalism, and sees the global poor as a leftover from the international economic system - a residue. But this residue is not created by the economic system: it is simply unable to absorb it. The solution is to make the economic system more efficient so that it does absorb this leftover element. And so where national economies lie outside of the global economic order, barriers need to be deconstructed so that those economies become incorporated into the international system. Or, where certain sections of a national economy that is incorporated into the international system remain on the outside, then reform has to 
take place such that they are included. That international system as it were moves in and soaks up the poor so that they become part of the global order. The presupposition is, of course, that it is better to be inside the capitalist economic order than outside of it.

The structural approach comes out of the Marxist critique of liberalism, and sees the global poor as a product of the global economic order. For the neo-liberal position, the global poor are just on the outside of that order, but for the Marxist, they are produced by how the system is structured - the order itself produces the economic inside and the outside. And so the solution to global poverty cannot be to make the economic order more efficient, because that may have the effect of increasing the numbers in extreme poverty. Rather, the solution has to be to radically change the economic order so that it no longer produces an inside and an outside, because all are genuinely included in an egalitarian system of production and consumption, a system in which they are free and equal (autonomous) producers and consumers. These two forms of analysis can be applied to many issues, such as the position of women, ethnic minorities and the physically disabled, and not only in relation to the economic system, but also all kinds of political and social systems. Either these groups lie outside of those systems because of factors that have nothing to do with those systems or because there is a minor inefficiency in the system that can be tweaked, or those systems produce an inside and an outside such that the order is structured around the exclusion of certain others.

The stateless can be understood in this way, again not in relation to the global economic order but in relation to the global political order. We can see them as a leftover residue lying outside of the international system of sovereign states, either nothing to do with that system or because of some minor inefficiency of that system that can be tweaked. Or we see them as a structural failure, a product of that order, such that finding a solution to statelessness means asking radical question about the international political order. This is not so much a dispute between neo-liberals and Marxists, but between reformists and radical critics of the nation-state system. Carens 
can, to an extent, be seen as taking the former position, in that he believes his approach the migration and membership is compatible with the nation-state system more or less as it stands. For example, in his discussion of refugees he explains the obligation nation-states have to refugees in terms of the normative presuppositions of the nation-state system. That system organizes the world so that everybody ought to be assigned to a nation-state. However, in some cases that does not happen when states fail people either deliberately or through incapacity. "Because the state system assigns people to states, states collectively have a responsibility to help those for whom this assignment is disastrous" (Carens, 2013, p. 196). It does not take much to apply this argument to the stateless, and the clear implication is that the failure does not arise from the nation-state system itself, but from certain nation-states failing to behave, either deliberately or through incapacity, as we believe nation-states should.

\section{The theoretical inside/outside}

But while we have an interesting line of argument here about moral responsibility for the stateless -- whether we should see it a systemic failure or a domestic one -- I am not going to pursue this here. My focus in this essay is not how people become stateless but how the idea of statelessness is produced, not how the political system constructs an inside and an outside, but how liberal political theory constructs an inside and an outside. My main contention is that these two approaches - the residual and the structural - are embodied at the level of political theory itself. What we should notice is that not only are certain groups excluded from economic, political and social systems, but that they are excluded at the level of theory, from theoretical systems. Certain groups such as women, the physically disabled, non-white 'ethnic' groups, migrants and the stateless, have been excluded from liberal political theory. This, of course, is not news. Political theorists have been aware of this for decades and many have addressed it. But the point is to notice that we can understand that exclusion either as residual or structural. If residual, all we need to do is tweak our theory a bit to include them, and then carry on more or less as before. If structural, then we have to radically re-think out political theory in order for it to be genuinely 
exclusive, and that may involve re-thinking everything - we cannot go on as before. My contention in this essay is that this exclusion is structural; the inside and outside is produced by theory itself, and business as usual is not an option.

I first noticed exclusion at the level of political theory many years ago working on my $\mathrm{PhD}$ looking at the work of John Rawls in relation to the physically disabled. Rawls explicitly acknowledges that his theory applies to what he describes as the "normal range'. He says: ““،... it is reasonable to assume that everyone has physical needs and physiological capacities within some normal range", and his theory is for "those who are full and active participants in society, and directly or indirectly associated over the course of a whole life" (Rawls, 1978, p. 70, note 9). His theory therefore explicitly excludes those who are excluded from full and active participation in society. Although he suggests that he may be able to "attempt to handle these other cases later", it is extraordinary to realize that liberal political theory, as Rawls understands, is not for everybody, but only for the included. It is also interesting to note that these comments are not taken from his major book, A Theory of Justice, but from a paper, and from a footnote in that paper.

And so what we have here is a double exclusion, from practice and from theory, and the exclusion from theory reflects and is based upon the exclusion from practice. Rawls, though, obviously takes the residual view, with the supposition that we can ignore these difficult subjects for now, but once we have worked out the theory for the 'normal' we can bring them in later - all we need do is tweak the theory a little to include the excluded and we can go on much as before. The implication has to be, I think, that this is how the problem can be tackled in practice: We can make the practice work better from the point of view of justice for all those included in the practice, and at a later date tweak that practice to include those who have been excluded from it.

However, my view is that this is entirely mistaken and what we have here is a deeply structural challenge. Part of the problem is that when we come to include the 
excluded, we are attempting to include them within a theory that has been actively structured around their exclusion. This reflects the problem at the level of practice. If our practices have been fundamentally constructed around an idea of what it is to be 'able-bodied', including the physically disabled within them through some 'tweaking' is going to be highly problematic. What is needed is a fundamental re-think of those practices from the ground up treating all as equal members with no prior distinction between the 'able-bodied' and the 'disabled', and that may mean radically different practices. The same holds for theory.

What we realize is that theory has a topology, a shape. Historically, liberal theory has simply excluded the 'other', whether they be the physically disabled or in our discussion the stateless. It has not acknowledged their existence at all and has presented a false universalism. This means that their presence within theory becomes deeply disruptive and disturbing because, if I am right, it cannot be business as usual only now with the 'outsider' on board. The theory we have ended up with is exposed as deeply flawed and in need of radical critique.

My proposal is that this is how we should see the concept of the stateless in liberal political theory. Liberal political theory has notoriously been structured on the assumption that we are dealing with members of a nation-state (and Rawls shows us how, in fact, the focus is much narrower than that, as feminist theorists and those working on the concept of 'race' and other identity positions have pointed out more critically). This is an assumption that I have confronted in my work on migration, arguing that the migrant should be an equal figure with the citizen in any ethical discussion of immigration, rather than the interests of the citizen dominating theory. But equally, international political theory, when it does address the ethics of migration, is equally structured on the assumption that people, even if they are migrants, are members of some nation-state. And so we have to recognize that while we have confronted the fact that the migrant was not included within liberal political theory, we now have to recognize that the stateless are not included within international political theory, however cosmopolitan we believe that theory to be. 
The obvious reply to this critique is, of course, that we are addressing that absence, otherwise we would not be here now discussing the stateless. But my point is that we can't simply apply the political theory we have to the problem of statelessness, because the political theory we have does not acknowledge their existence, or rather it can only acknowledge their existence in a particular way. Even if we direct the theory towards statelessness as an issue, the theory constructs statelessness as a specific kind of problem, and keeps the stateless at the margins of theory, not allowing them to become the central problem of theory. It has to do this, because if it did allow the stateless to become the central problem of theory, they would expose that theory as fundamentally structurally flawed and incoherent.

When I wrote my book Philosophies of Exclusion: Liberal Political Theory and Immigration in 2000, the major aim of my argument was not, in fact, for open borders, but to show that addressing the question of membership has the potential to undermine the entire coherence of liberal political theory. Immigration is not some marginal question which we can add on to theory, but goes to the heart of that theory and exposes it as fundamentally flawed. My conclusion to that book was that liberal theory had a choice, either to embrace open borders or embrace its own incoherence, and since then many liberal theorists have indeed embraced that incoherence rather than accept the open-borders implication of liberal theory and tried to make sense of it. Whether they have succeeded or not is a matter for their readers.

\section{4: The topography of theory}

The question of statelessness reveals that the structural flaws go much deeper than I accounted for in Philosophies of Exclusion. The problem we face is that liberal political theory has been an 'insider theory', a body of theory that privileges the voice of the insider, the one who possesses statehood, the citizen. That privilege, at the extreme, has meant that this is the only voice acknowledged as existing, but even if we recognize the existence of the stateless as a problem for political theory, it may 
still be that the voice of the citizen is acknowledged as the only legitimate voice to be heard. The stateless are included in the theory, but as a problem for the citizen, a problem that must be solved in the interests of the citizen. Any solution of that problem has to keep the interests of the citizen at the centre, in the same way that the theory has always been structured around the interests of the citizen.

Rawls tells us, unwittingly perhaps, that the problem is even worse than this, that the theory has been constructed around the interests of a particular kind of citizen, one who is a member of the 'normal range' however we construct that range. But my contention in this paper is that the problem is even worse than this. Not only has liberal theory been 'insider theory' with a specific topology, theorizing from inside a nation-state, it has also had a specific topography, theorizing from inside a particular kind of nation-state in a particular area of the world. Liberal theory has a geographical shape, as a body of theory structuring a viewpoint on migration and membership centred upon the interests not only of those who already have membership of a state, but membership of a particular kind of nation state in a particular location in the world. This means that any solution to the problem of statelessness theory produces will be structured around the interests of those specific members. So the relationship we are trying to understand here is not simply between statelessness and citizenship, but between statelessness and citizenship of liberaldemocratic states in the Global North.

This topography of theory means that any solution to the question of statelessness constructed within liberal political theory even in its international form cannot be genuinely inclusive and egalitarian, because the negotiation on which that solution is based cannot take place on an equal basis. Indeed, it is likely that any negotiation will still only be between those on the inside, with the stateless remaining on the outside, excluded as participants in any negotiation of a solution. There is still a core and periphery of theory, with the other - in this case, the stateless - confined to the periphery and the core structured around the interests of the insider, the citizen of a particular kind of nation-state in a particular location. They have to be so confined because, as we saw earlier, to bring them to the centre shows the theory to be deeply 
flawed, and shows the subject - the citizen/member - at the centre of the theory, the subject who's interests it prioritizes, as equally deeply structurally flawed. The integrity of the subject depended on the exclusion of the 'other', and their position, identity, interests and power still depend on the confinement of the 'other' to the periphery even if we acknowledge their existence.

\section{5: The psychology of theory}

The presence of the 'other' in political theory - that against which the core identity is defined - is therefore theoretically disturbing and disruptive. Firstly, it reveals that the core identity is not universal, but particular -- it exposes what Vron Ware and Les Back describe as the 'unwitting' solipsism of the "individual unaccustomed to questioning the idea that she or he occupies a privileged political and cultural category" (Ware and Back, 2002, p. 5). Secondly, it reveals that the core identity is not a pre-theoretical given, but a theoretical construct, which can therefore be deconstructed. Thirdly, it reveals that the core identity is flawed - the process of exclusion of the 'other' creates tensions and antagonisms which cannot be resolved without a radical, ground-up revision of the entire theoretical landscape. In the words of Marx and Engels, all that is solid melts into air. Therefore the presence of the 'other' must be tightly controlled and confined - the problem of the 'other' must be solved, but in a way that maintains and even strengthens the position of the core identity.

I want to argue that we need to acknowledge, not only theoretical, but also psychological disruption, and indeed that these two are connected. Imogen Tyler, drawing on Julia Kristeva (who in turn is drawing on Jacques Lacan who is drawing on Sigmund Freud), has written about 'revolting subjects', using the core concept of abjection. The abject is precisely that revolting residue we saw in the neoliberal approach to the global poor. Barbara Creed writes that the sources of the abject are those things that disrupt the boundary between the living body and its own death, such as bodily wastes and decay. These are things that threaten our identity as a member of 
humanity, such that we wish to expel them behind a border which will protect us from them. However, they are part of who we are, so that the expulsion has to be constant and the border is constantly threatened. Because of this constant need to repel, ritual becomes centrally important to maintaining the boundary between the human and the non-human, and that ritual has to become more detailed, complex and intense. Creed says that the abject has to be radically excluded and "deposited on the other side of an imaginary border which separates the self from that which threatens the self"' (Creed, 1993, p. 9; See Cole, 2006 pp. 113-117).

There is much more to be said about the abject and Imogen Tyler's use of it, but for now I want to point to the small conceptual leap in applying this to the politics of membership and migration as boats of desperate humanity crossing the Mediterranean are constructed as abject and to be repelled, for some at all costs, likened recently to cockroaches by a columnist in the United Kingdom newspaper the $S u n ;{ }^{4}$ and to those gathered at Calais, described by United Kingdom Prime Minister David Cameron as a 'swarm' of migrants threatening to overwhelm the United Kingdom. ${ }^{5}$ Although the United Nations High Commissioner for Human Rights, Zeid Ra'ad Al Hussein condemned the Sun for the article ${ }^{6}$, the attitude in Europe continues to darken, with French Prime Minister Manuel Valls claiming that the European Union may 'die' if the current levels of refugees entering the region continue. ${ }^{7}$

Tyler applies the notion of the abject to travelers, rioters, the poor and asylum seekers as well as migrants. The additional conceptual leap I am suggesting here is to apply the idea of the abject as a critique not only of political practice but also of political theory and its construction of - for the purposes of this discussion - the stateless. Indeed, the stateless present an even more radical challenge. If we assume that migrants have membership of some other state then they have a home and we need not allow them to enter ours. The stateless have no home, and so to place them at the centre of theory destroys the border that constitutes the integrity of the core subject in a radical way and so disrupts the subject itself as it loses any property that distinguishes it from the 'other'. Any acceptable solution to the migrant crisis in 
political theory or practice must be one that strengthens the boundary between the inside and outside rather than dissolves it. At the level of practice the European Union's ten-point programme for dealing with the unfolding tragedy in the Mediterranean was certainly aimed at strengthening the border, for example including proposals to destroy the boats used by people smugglers; and the response by the British and French governments at Calais was to build more fences, and we build fences at the level of theory as well. But this strengthening of the border, either in practice or theory, makes no sense in response to the challenge of statelessness, because the very notion of the state to be defined by the fence makes no sense. The stateless are abject in the extreme - psychologically and theoretically revolting.

And so the neo-liberal residual approach reduces the stateless to a revolting residue. The challenge for the structural approach is how to build a genuinely inclusive theoretical context within which all have equal voices in reaching an egalitarian settlement based on universal principles of justice. This approach is based on a realization that everything has to be up for negotiation - there can be no fixed points, because what we take to be fixed points have been fixed by the old topology/ topography of theory, and it is those fixed points that are the problem, and to think that we can arrive at a solution to statelessness based around those fixed points is the mistake. The core idea of this discussion is not in fact statelessness, but membership it is our idea of membership that constitutes and constructs the idea of statelessness, because it is the way in which membership is constructed in theory and practice that dispossesses those who do not meet its criteria. At the level of theory, it is not the idea of statelessness that is the problem, but the idea of membership itself. And that means that at the level of practice, it is not the stateless who are the problem, but those of us who possess membership.

\section{6: The meaning of membership}

And so the theoretical basis for discourses of membership and mobility must be challenged and transformed. What membership means has to be fought over, rather than taken as our starting point. The fight is not just for membership, but also for its 
meaning. And what we realize is that its meaning will be determined not by theorists and policy makers, but also by the stateless themselves acting out these ideas in their everyday lives. What is needed is dialectic between theory and lived experience. This has always been how moral and political concepts have been determined - not through abstract thought, but through political and practical struggle, and through ordinary people seeking to improve their lives and the lives of those around them in conditions of political and economic oppression. Political theory must become cosmopolitan in the true sense of the word, by providing space for all these voices and experiences be embracing our common humanity and dissolving the boundaries that separate 'us' from ' them'. Only then can we negotiate the terms of membership as equals.

The way in which the privileging of the voice of the insider is deeply ingrained within political theory is shown by Seyla Benhabib's use of discourse ethics to establish a human right to membership. Her discourse between the insider and the outsider goes as follows (note that from the beginning she, as the speaker, is the insider): "If you and I enter into a moral dialogue with one another, and if I am a member of a state of which you are seeking membership and you are not, then I must be able to show you with good grounds, grounds that would be acceptable to each of us equally, why you can never join our association and become one of us. These must be grounds that you would accept if you were in my situation and I were in yours. Our reasons must be reciprocally acceptable; they must apply to us equally" (Benhabib, 2004, p. 138). In order to be acceptable, such grounds would be to do with qualifications, skills and resources (Benhabib, 2004, p.139). But note that the crucial aspect of the discourse is that these must be grounds that you would accept if you were in my situation. In other words, the outsider must think from the perspective of the insider, and so once more the perspective of the insider is privileged. The sentence should at least read: These must be grounds that you would accept if you were in my situation and I would accept if I were in yours. As it stands, there is no reciprocity here. If the grounds for exclusion are to be genuinely "acceptable to us equally", then they have to be acceptable to the outsider as outsider. And equally importantly, they must be 
contested against grounds for inclusion which must carry equal weight in the exchange.

Lori Watson points out: "The emphasis on reasons we could not reasonably reject as the standard of moral justification requires us to recognize that such reasons have the character they do, in part, because they are reasons we can share-as moral equals. Acknowledging that immigrants stand in a political relationship vis-à-vis the state of intended migration requires acknowledging that the state is obligated to offer justifications that could not be reasonably rejected for its principles. This, however, also requires acknowledging the immigrant as a reason-giver in this context, and as an equal" (Watson, 2008, p. 988). But in order for the migrant or, for the purposes of our discussion today, the stateless to be an equal in this exchange, we must be able to give our reasons from positions of equality, and to make this possible we have to be prepared to think outside of the conventional political frameworks that position the stateless as the 'problem' figure in this relationship. It is not the stateless who are the problem, but the relationship itself, a relationship which privileges the reasons of the 'insider' and renders the 'outsider', in this case the stateless, silent. 


\section{References}

Benhabib, S. (2004) The Rights of Others. Cambridge: Cambridge University Press.

Carens, J. H. (2013) The Ethics of Immigration. Oxford: Oxford University Press.

Cole, P. (2000) Philosophies of Exclusion: Liberal Political Theory and Immigration. Edinburgh: Edinburgh University Press.

Cole, P. (2006) The Myth of Evil. Edinburgh: Edinburgh University Press.

Cole, P. (2014) Carens and the Problem of Method. Ethical Perspectives 21 (4), pp. 600-607.

Cole, P. (2015) At the borders of political theory: Carens and the ethics of immigration. European Journal of Political Theory Volume 14 (4), pp. 501-510

Creed, B. (1993) The Monstrous Feminine: Film, Feminism, Psychoanalysis. Abingdon: Routledge.

Rawls, J. (1978) The basic structure as subject. Goldman, A. and Kim, J. eds. Valies and Morals. Dordrecht: Reidel.

Tyler, I. (2013) Revolting Subjects: Social Abjection and Resistance in Neoliberal Britain. London: Zed Books.

Ware, V. and Back, L. (2002) Out of Whiteness: Colour, Politics, and Culture. Chicago: Chicago University Press.

Watson, L. (2008) Equal justice: comment on Michael Blake's immigration and political equality. San Diego Law Review, 45, pp. 981-988. 


\section{Notes}

${ }^{1}$ See Carens (2013).

${ }^{2}$ See Cole (2014) and Cole (2015).

${ }^{3}$ See Galston (2010) and Rossi and Sleat (2014).

${ }^{4}$ See http://www.theguardian.com/global-development/2015/apr/24/katie-hopkinscockroach-migrants-denounced-united-nations-human-rights-commissioner.

${ }^{5}$ See http://www.bbc.co.uk/news/uk-politics-33714282.

${ }^{6} \mathrm{See}$ http://www.theguardian.com/global-development/2015/apr/24/katie-hopkinscockroach-migrants-denounced-united-nations-human-rights-commissioner.

${ }^{7}$ See http://www.telegraph.co.uk/news/worldnews/europe/france/12114438/FrenchPrime-Minister-Migration-crisis-could-kill-off-the-European-Union.html. And see my "Europe's Response to Migrant Tragedy in the Mediterreanean", Politics in Action, http://www.e-ir.info/2015/04/27/europes-response-to-migrant-tragedy-in-themediterranean/. 